\title{
Fusiform Rust of Southern Pines: A Major Success for Forest Disease Management
}

\author{
Robert A. Schmidt
}

School of Forest Resources and Conservation, Institute of Food and Agricultural Sciences, University of Florida, Gainesville 32611. Accepted for publication 7 March 2003.

\begin{abstract}
Schmidt, R. A. 2003. Fusiform rust of southern pines: A major success for forest disease management. Phytopathology 93:1048-1051.

The effective management of fusiform rust in slash and loblolly pine plantations is a major success story for disease management scientists and practitioners in the southeastern United States. This disease, which reached epidemic proportions by the 1960s, resulted from anthropogenic causes associated with intensive pine culture and greatly inhibited the optimum management of slash and loblolly pine throughout extensive areas of the southern pine region. Successful management of this disease was made possible by the combined resources and personnel of federal and state agencies, universities, and the forest industry. Chief among these personnel were research pathologists, geneticists, and silviculturalists.

Following early studies on the biology of the fusiform rust pathosystem, research on epidemiology, host resistance, and pathogen variability slowly but steadily progressed. Testing of pine selections for resistance was facilitated by the establishment of a rust screening center. Fortunately, genetic rust resistance is relatively abundant in both slash and loblolly pines and has become the foundation for the management of the disease. Rust resistant half- and full-sib progeny from resistant parents established in seed orchards are routinely planted, especially in high-rusthazard areas. Several important lessons in disease management have been learned or remembered during the progress of this research. Perhaps the ecologically fit fusiform rust pathogen will have additional instructions for us in the future, but for now resistance is an effective management strategy.
\end{abstract}

Fusiform rust, caused by Cronartium quercuum (Berk.) Miyabe ex Shirai f. sp. fusiforme, has increased to epidemic proportion in slash and loblolly pine plantations throughout extensive areas of the South since the late 1950s and early 1960s (14). Previously this disease, first reported near the turn of the last century, was neither widespread nor prevalent. There is evidence the disease spread and intensified from Mississippi to the Atlantic coast and south to Florida (6). The pathosystem is indigenous to the southeastern United States, which is likely the center of origin and a region of great genetic diversity in host and pathogen (44). The pathogen is not known to occur naturally outside the southern United States, although some species of pine-oak rusts occur elsewhere. The increase in fusiform rust incidence and therein its role as a major limiting factor in the management of slash and loblolly pines over extensive areas resulted from changes in the forest ecosystem that accompany intensive pine management, principally plantation culture (33). The pathogen is not favored nor abundant in old growth natural stands but is greatly favored in young, rapidly growing pine plantations, especially those established in high-rust-hazard areas, where $90 \%$ or more of rustsusceptible trees can be infected by age 5 (14).

Current comprehensive losses caused by fusiform rust are not known. In 1972 estimates were 28 million dollars annually to stumpage, excluding mortality (30). The most recent estimate (1986) was 35 million dollars annually in five states (Florida, Georgia, North Carolina, South Carolina, and Virginia) (1); losses also

Corresponding author: R. A. Schmidt; E-mail address: raschmidt@mail.ifas.ufl.edu

Publication no. R-09257 of the Florida Agriculture Experiment Station.

Publication no. P-2003-0602-050

(c) 2003 The American Phytopathological Society occur in Alabama, Arkansas, Louisiana, Mississippi, Oklahoma, and Texas. Losses occur mostly as mortality to young pines. When 1- to 5-year-old trees develop stem galls, they often die before harvest age or become deformed and unmerchantable. Trees with severe stem galls may die throughout the rotation, especially if to high-velocity winds. Forest inventory data (1987 to 1993) from 11 southeastern states estimate that 1.2 million acres of planted slash and loblolly pines had $\geq 50 \%$ of trees with potentially lethal infections (52).

Fusiform rust has affected nearly all forest management practices, some quite significantly. Forest managers are faced with the dilemma-more growth, more rust. Nursery management, site preparation, species selection, fertilization, thinning, pruning, controlled burning, and rotation length are impacted by the disease. Inventory procedures and growth and yield modeling (26) must consider the disease. Perhaps the most significant impact has been on tree improvement programs in which new emphasis was placed on the selection, testing, and deployment of potentially rustresistant families. The continued improvement and stability of rust resistance remains a concern of these programs.

Biology. C. quercuum f. sp. fusiforme, pathogenic on slash pine (Pinus elliottii Engelm. var. elliottii), loblolly pine (P. taeda L.), and longleaf pine (P. palustris L.), is one of four form species of the pine-oak rusts in the United States (5). Other form species are banksianae on jack pine (P. banksiana Lamb.), virginianae on Virginia pine ( $P$. virginiania Mill.), and echinatae on shortleaf pine ( $P$. echinata Mill.). Another pine-oak rust pathogen, $C$. strobilinum Hedgc. \& Hahn on slash pine (cone rust), is also recognized. C. quercuum f. sp. fusiforme is a macrocyclic heteroecious biotroph producing spermatia and aecia on pine galls and uredinia and telia on the undersides of oak leaves. The pathogen is perennial on pine and annual on oak. The pathosystem is discontinuous; pine-to-pine infection does not occur. Aeciospores from 
pine galls are wind-disseminated to infect succulent oak leaves in the spring. Several weeks later, wind-disseminated basidiospores from oak infect succulent pine shoots, resulting in branch and stem galls after 6 to 9 months $(7,15,27,34)$.

Many species of southern red oaks (Quercus spp.) are susceptible and their epidemiological importance varies with location (9). In the Coastal Plain, water oak (Q. nigra L.) and laurel oak (Q. laurifolia Michx.) are important alternate hosts; further north, red oak $(Q$. rubra L.) becomes important. Of the commercial southern pines, slash, loblolly, and longleaf are susceptible, whereas shortleaf is considered immune $(7,27)$. Although fusiform rust is known only to occur in the southeastern United States, several species of pine from western United States, Central America, and Mexico are susceptible when artificially inoculated, as is at least one species of oak from California $(10,23)$.

It is a concern that significant gaps exist in our knowledge of fundamental biology, e.g., pathogen life history and genetics and host-parasite interactions. Many details of biology were bypassed since the early promise of resistance focused research on the applied aspects of host-pathogen relations and epidemiology.

Epidemiology. In the natural forest, with limited human activity, indigenous pathosystems usually reach a balance at endemic disease levels. Such was the case historically (at least in the recent past) with fusiform rust in natural pine forests, where this disease was of rare occurrence at the turn of the 20th century (14). However, in our desire (and need) for more productive forests, requiring more intensive forest management, we have created conditions very favorable for the increase and spread of fusiform rust (33).

Since World War II, intensive planting efforts replaced natural regeneration and resulted in extensive areas of young, rapidly growing susceptible slash and loblolly pine plantations. This most successful regeneration effort significantly altered the species composition, but especially the age composition of the preexisting forest, in favor of the rust pathogen and the resulting disease. Old growth forests - often of the more rust-resistant longleaf pinewere replaced by young plantations of susceptible slash and loblolly pines. For example, in Florida, pine plantations increased from an estimated 291,000 acres in 1952 to 5.59 million acres by 1990 (52). In the Southeast, pine plantations increased from 1.0 to 22.6 million acres. The shift to younger age-classes accompanying the increase in plantations has contributed greatly to the increase in rust incidence. Silvicultural practices that improve pine growth, e.g., fertilization, vegetative competition control, genetic growth rate improvement, and intensive site preparation, result in rapid and succulent growth of young trees and favor rust development, both infection and sporulation $(8,24,41,42)$.

The alternate oak hosts, the source of basidiospore inoculum for the infection of pine, are critical for disease development. The potential for rust on pines increases with the abundance and nearness of infected oaks (51). Basidiospores are transported over long distances (at least $1 / 2$ mile) to infect pine (11). On the betterdrained upland sites, where oaks can flourish in the absence of fire, reduced prescribed burning and absence of wildfires, which has occurred over the last 50 to 70 years, have favored oak regeneration and allowed oaks and rapidly growing young pines to occur in close proximity. Then too, some silvicultural practices favor oak regeneration, e.g., wind-rowing and chopping. Forestry incentive programs have resulted in an increase of planting on former agricultural sites (i.e., better-drained soils with abundant oaks). In contrast, the poorer-drained coastal flatwood sites do not support the abundance of oaks $(7,41)$.

Temperature and moisture requirements for infection of pine and oak were determined early $(45,46)$ and greatly aided our understanding of rust incidence in the natural and plantation ecosystem. Most important is surface moisture in the form of rain or dew on succulent oak leaves and pine shoots. Unfortunately, over extensive areas of the Southeast, both moisture and temperature are not limiting. This is especially true in young pine plantations in which abundant plant surface moisture occurs almost daily for long periods during the critical spring season when sporulation and infection occur. Fusiform rust may be limited by climatic factors on the northern and western extremities of its geographic range (7). It is also apparent that rust incidence varies among years and locations $(14,35,40)$ depending, in part, on favorable or unfavorable weather at critical periods in the disease cycle. Determining the optimum temperature and moisture conditions for the successful inoculation of pine and oak seedlings was a critical step in the search for rust resistance.

Regional rust hazard maps (52) and guidelines for predicting rust incidence on land management units (34) were developed to aid forest managers in making a priori decisions, especially decisions of where to deploy rust-resistant and rust-susceptible planting stock (40). Resistant seedlings were deployed to high-rusthazard areas, and growth-improved seedlings with little or no rust improvement were deployed to perennially low-rust-hazard areas.

Management of rust. There are several pest management strategies that mitigate losses caused by fusiform rust depending on landowner objectives and rust hazard $(2,31,34,36)$. There are guidelines to reduce potential losses in infected stands (4) and tactics to avoid severe losses in newly established plantations. The latter include site preparation techniques that reduce oak abundance, delaying fertilization in very young plantations, culling rustinfected seedlings from the nursery, and pruning branch galls, which could later grow into the stem. An important research contribution was the development of Bayleton $\AA$ to control fusiform rust in nurseries $(19,49)$, but most important, and the primary reason for success, was the development of rust-resistant planting stock $(12,16,29,32,37,39,43,50)$.

Development of rust-resistant planting stock. In the mid1950s forest scientists recognized that progeny of some openpollinated pine selections remained rust-free when planted in field tests (3). This began the successful research and development programs on genetic resistance of southern pine to fusiform rust. Plant pathologists, geneticists, and others in federal and state agencies, and in private industry in the southeastern United States, were involved. Cooperative tree improvement programs (Florida, Georgia, North Carolina, and Texas) selected and field-tested improved varieties (families) of slash and loblolly pines throughout the region. For example, the cooperative tree improvement program at the University of Florida established over 800 field progeny tests, many of which were scored for fusiform rust at multiple ages (37). Promising families were further tested in high-rusthazard areas (50) and new selections were made in plantations where rust incidence was $\geq 90 \%$. One innovative approach was the creation of special seed production areas from plantations that were severely $(>90 \%)$ infected. Infected trees were rogued from these plantations and rust-free phenotypes produced seed with significant rust improvement within 3 years (13). Methods were developed to artificially inoculate pine seedlings (17). Tree improvement efforts were greatly facilitated when a screening center was established by the U.S. Forest Service at Bent Creek near Asheville, NC (20). This facility provided a standard method to screen 6-week-old seedlings for rust resistance for tree improvement programs and also aided research pathologists and geneticists to study the nature of rust resistance. A performance index was developed at the center based on resistant reaction types, e.g., hypersensitive-like lesions and small galls, which greatly improved the correlation between greenhouse inoculations and field progeny tests (53). Research on the morphology and histopathology of pine host reaction types led to a better understanding of host-pathogen relations $(18,25)$. Studies of pathogen variability showed $C$. quercuum f. sp. fusiforme to be quite variable $(21,28,47,48)$. Major genes have been identified that are associated with pine host resistance $(22,54)$ and components of partial resistance have also been reported (38). Studies on pathogen genetics and frequency of and selection for virulence have only begun. Of course, the long-term 
stability of host resistance is a continuing concern, especially in view of the abundance of pathogenic variability and the specter of clonal plantations. But early results are promising with regard to family stability, at least in the present management scheme.

In the meantime, rust incidence and mortality have been significantly reduced, especially in high-rust-hazard areas. Millions of acres of industrial and nonindustrial lands are being planted with improved seedlings, most containing some level of rust resistance. A recent benefit/cost analysis estimated that research on fusiform rust returned $\$ 5$ to $\$ 20$ for each dollar invested, depending on management objectives and strategies (32).

Lessons learned. In pursuit of fusiform rust resistance in southern pines, many lessons have been learned, relearned, or at least exemplified, especially those lessons pertaining to an indigenous endemic forest pathosystem. A few of these lessons related to disease resistance and epidemiology are described below. (i) An indigenous endemic pathosystem can rapidly become epidemic with changes in forest management practices. Plantations stripped of natural defenses became vulnerable to an " $r$ "-type pathogen as the balance was shifted in favor of C. quercuum f. sp. fusiforme. (ii) Rust resistant slash and loblolly pine genotypes are not rare in this center of origin and, of course, neither are pathotypes. (iii) Even though rapidly growing phenotypes were most susceptible to fusiform rust, both rust resistance and rapid growth occur in specific genotypes. (iv) Genetic rust resistance is a useful and valuable disease management strategy in a plantation ecosystem, even in the face of an r-type pathogen. (v) The fusiform rust pathosystem, likely because of its discontinuous epidemiology (no pine-to-pine infection), appears to be buffered against strong selection pressure for virulence in the pathogen.

Future prospects. Beginning in the 1950s, fusiform rust was a major priority of state, federal, and industrial forestry research programs in the southeastern United States. Since the mid-1990s, with retirements and changes in programs, research on fusiform rust has decreased. However, rust still remains an important component of several biotechnology research programs and tree improvement cooperatives. To date, more than 1,000 research papers on fusiform rust have been published.

Future research will focus on questions of the stability of resistance in pine and virulence in the pathogen. Despite the present success there are reasons for concern: (i) pathogen variability is abundant, (ii) temporal and spatial interactions (genotype by environment) occur among resistant pine genotypes, and (iii) major genes in pine are associated with resistance. In addition, clonal forestry is a goal of intensive plantation culture. Surely it is prudent to maintain a viable proactive fusiform rust research program.

\section{LITERATURE CITED}

1. Anderson, R. L., McClure, J. P., Cost, N. D., and Uhler, R. J. 1986. Estimating fusiform rust losses in five southeast states. South. J. Appl. For. 10:237-240

2. Anderson, R. L., Schmidt, R. A., and Snow, G. A. 1984. Integrated pest management in regeneration-early growth phase of pine stands-diseases. Pages 45-71 in: Proc. Integrated Forest Pest Management Symp. S. J. Branham and G. D. Hertel, eds. U.S. Dep. Agric. For. Serv., Athens, GA.

3. Barber, J. C., Dorman, K. W., and Bauer, E. 1957. Slash pine progeny tests indicate genetic variation in resistance to rust. U.S. Dep. Agric. For. Serv. Southeast. For. Exp. Stn. Res. Note 104.

4. Belanger, R. P., Miller, T., Zarnoch, S. J., Fraedrich, S. W., and Godbee, J. F. 2000. An integrated approach toward reducing losses from fusiform rust in merchantable slash and loblolly pine plantations. U.S. Dep. Agric. For. Serv. South. Res. Stn. Res. Pap. SRS-23.

5. Burdsall, H. H., and Snow, G. A. 1977. Taxonomy of Cronartium quercuum and C. fusiforme. Mycologia 69:503-508.

6. Dinus, R. J. 1974. Knowledge about natural ecosystems as a guide to disease control in managed forests. Pages 184-190 in: Proc. Am. Phytopathol. Soc., Vancouver, B.C.

7. Dinus, R. J., and Schmidt, R. A. (eds.) 1977. Management of fusiform rust in southern pines. Pines: Symp. Proc., University of Florida,
Gainesville.

8. Dinus, R. J., and Schmidtling, R. C. 1971. Fusiform rust in loblolly and slash pines after cultivation and fertilization. U.S. Dep. Agric. For. Serv. South. For. Exp. Stn. Res. Pap. SO-68.

9. Dwinell, L. D. 1974. Susceptibility of southern oaks to Cronartium fusiforme and Cronartium quercuum. Phytopathology 64:400-403.

10. Dwinell, L. D., and Powers, H. R., Jr. 1974. Potential for southern fusiform rust on western pines and oaks. Plant Dis. Rep. 58:497-500.

11. Froelich, R. C., and Snow, G. A. 1986. Predicting site hazard to fusiform rust. For. Sci. 32:21-35.

12. Goddard, R. E., and Schmidt, R. A. 1971. Early identification of fusiform rust resistant slash pine families through controlled inoculation. Pages 31-36 in: Proc. South. For. Tree Improve. Conf., 11th. South. For. Tree Improve. Comm. Pub. No. 33.

13. Goddard, R. E., Schmidt, R. A., and Vande Linde, F. 1975. Effect of differential selection pressure on fusiform rust resistance in phenotypic selections of slash pine. Phytopathology 65:336-338.

14. Griggs, M. M., and Schmidt, R. A. 1977. Increase and spread of fusiform rust. Pages 32-38 in: Proc. Management Fusiform Rust South. Pines. R. J. Dinus and R. A. Schmidt, eds. University of Florida Press, Gainesville.

15. Hedgcock, G. G., and Siggers, P. V. 1949. A comparison of pine-oak rusts. U.S. Dep. Agric. Tech. Bull. 978.

16. Hodge, G. R., Schmidt, R. A., and White, T. L. 1990. Substantial realized gains from mass selection of fusiform rust-free trees in highly infected stands of slash pine. South. J. Appl. For. 14:143-146.

17. Jewell, F. F. 1960. Inoculation of slash pine seedlings with Cronartium fusiforme. Phytopathology 50:48-51.

18. Jewell, F. F., Jewell, D. C., and Walkinshaw, C. H. 1980. Histopathology of the initiation of resistance-zones in juvenile slash pine to Cronartium quercuum f. sp. fusiforme. Phytopathol. Mediterr. 19:8-12.

19. Kelley, W. D., and Runion, G. B. 1991. Control of fusiform rust on loblolly and slash pine seedlings in forest nurseries in the southeastern United States. Pages 338-340 in: Rusts of Pines. Proc. Int. Union For. Res. Organ. Work. Party Conf. Y. Hiratsuka, J. K. Samoil, P. V. Blenis, P. E. Crane, and B. L. Laishley, eds. Can. Info. Rep. NOR-X-317.

20. Knighten, J. L., Young, C. H., McCartney, T. C., and Anderson, R. L. 1988. Resistance screening center procedures manual: A step-by-step guide used in the operational screening of southern pines for resistance to fusiform rust. U.S. Dep. Agric. For. Serv., Asheville, NC.

21. Kuhlman, E. G. 1990. Frequency of single-gall isolates of Cronartium quercuum $\mathrm{f}$. sp. fusiforme with virulence toward three resistant loblolly pine families. Phytopathology 80:614-617.

22. Kuhlman, E. G., Amerson, H. V., Jordan, A. P., and Pepper, J. O. 1997. Inoculum density and expression of major gene resistance to fusiform rust disease in loblolly pine. Plant Dis. 81:597-600.

23. Lambeth, C. C., Dvorak, W. S., and Young, C. H. 1997. Fusiform rust resistance of Central American and Mexican pine species compared with loblolly and slash pines. Page 207 in: Proc. 24th Biennial South. For. Tree Improve. Comm. Publ. 46.

24. Miller, T. 1972. Fusiform rust in planted slash pines: Influence of site preparation and spacing. For. Sci. 18:70-75.

25. Miller, T., Cowling, E. B., Powers, H. R., Jr., and Blalock, T. E. 1976. Types of resistance and compatibility in slash pine seedlings infected by Cronartium fusiforme. Phytopathology 66:1229-1235.

26. Nance, W. L., Froelich, R. D., Dell, T. R., and Shoulders, E. 1982. A growth and yield model or unthinned slash pine plantations infected with fusiform rust. Pages 275-282 in: Proc. 2nd Biennial South. Silvic. Res. Conf. E. P. Jones, Jr., ed. U.S. Dep. Agric. For. Serv., Atlanta, GA.

27. Powers, H. R., Jr. 1975. Relative susceptibility of five southern pines to Cronartium quercuum. Plant Dis. Rep. 59:312-314.

28. Powers, H. R., Jr. 1980. Pathogenic variation among single-aeciospore isolates of Cronartium quercuum f. sp. fusiforme. For. Sci. 26:280-282.

29. Powers, H. R., Jr., Kraus, J. F., and Duncan, H. J. 1976. Development of rust resistant slash and loblolly pines in Georgia. Ga. For. Res. Counc. For. Res. Pap. 87.

30. Powers, H. R., Jr., McClure, J. P., Knight, H. A., and Dutrow, G. F. 1975. Fusiform rust: Forest survey incidence data and financial impact in the south. U.S. Dep. Agric. For. Serv. Southeast. For. Exp. Stn. Res. Pap. SE127.

31. Powers, H. R., Jr., Miller, T., and Belanger, R. P. 1993. Management strategies to reduce losses from fusiform rust. South. J. Appl. For. 17:146-149.

32. Pye, J. M., Wagner, J. E., Holmes, T. P., and Cubbage, F. W. 1997. Positive returns from investment in fusiform rust research. U.S. Dep. Agric. For. Serv. South. Res. Stn. Res. Pap. SRS-4.

33. Schmidt, R. A. 1978. Diseases in forest ecosystems: The importance of functional diversity. Pages 287-315 in: Plant Disease: An Advanced Treatise. Vol. II. How Disease Develops in Populations. J. G. Horsfall and E. B. Cowling, eds. Academic Press, New York.

34. Schmidt, R. A. 1998. Fusiform rust disease of southern pines: Biology, 
ecology and management. Univ. Fla. Agric. Exp. Stn. Inst. Food Agric. Sci. Tech. Bull. 903.

35. Schmidt, R. A., and Allen, J. E. 1991. Temporal and spatial variation affecting fusiform rust hazard prediction in slash pine plantations in the southeastern United States. Pages 139-148 in: Rusts of Pine. Proc. Int. Union For. Res. Organ. Workshop Party Conf. Y. Hiratuska, J. K. Samoil, P. V. Blenis, P. E. Crane, and B. L. Laishley, eds. Can. Info. Rep. NOR$\mathrm{X}-317$.

36. Schmidt, R. A., Allen, J. E., Belanger, R. P., and Miller, T. 1995. Influence of oak control and pine growth on fusiform rust incidence in young slash and loblolly pine plantations. South. J. Appl. For. 19:151156.

37. Schmidt, R. A., and Goddard, R. E. 1971. Preliminary results of fusiform rust resistance from field progeny tests of selected slash pines. Pages 3744 in: Proc. South. For. Tree Improve. Conf., 11th. South For. Tree Improve. Comm. Publ. 33.

38. Schmidt, R. A., Gramacho, K. P., Miller, T., and Young, C. H. 2000. Components of partial resistance in the slash pine-fusiform rust pathosystem. Phytopathology 90:1005-1010.

39. Schmidt, R. A., Holley, R. C., and Klapproth, M. C. 1985. Results from operational plantings of fusiform rust-resistant slash and loblolly pine in high-rust-incidence areas in Florida and Georgia. Pages 33-41 in: Rusts of Hard Pines. J. Barrows-Broaddus and H. R. Powers, Jr., eds. Proc. Int. Union For. Res. Organ. Workshop Party Conf. S2-06-10.

40. Schmidt, R. A., Holley, R. C., Klapproth, M. C., and Miller, T. 1986. Temporal and spatial patterns of fusiform rust epidemics in young plantations of susceptible and resistant slash and loblolly pines. Plant Dis. 70:661-666.

41. Schmidt, R. A., Jokela, E. J., Allen, J. E., Belanger, R. P., and Miller, T. 1990. Association between fusiform rust incidence and CRIFF soil classification for slash pine plantations in the Coastal Plain of Florida and Georgia. South. J. Appl. For. 14:39-43.

42. Schmidt, R. A., Miller, T., Holley, R. C., Belanger, R. P., and Allen, J. E. 1988. Relation of site factors to fusiform rust incidence in young slash and loblolly pine plantations in the Coastal Plain of Florida and Georgia. Plant Dis. 72:710-714.

43. Schmidt, R. A., Powers, H. R., Jr., and Snow, G. A. 1981. Application of genetic disease resistance for the control of fusiform rust in intensively managed southern pine. Phytopathology 71:993-997.
44. Schmidtling, R. C. 1985. Co-evolution of host/pathogen/alternate host systems in fusiform rust of loblolly and slash pines. Pages 13-19 in: Rust of Hard Pines. J. Barrows-Broaddus and H. R. Powers, eds. Proc. Int. Union For. Res. Organ. Workshop Party Conf. S2-06-10.

45. Snow, G. A. 1968. Basidiospore production by Cronartium fusiforme as affected by suboptimal temperatures and preconditioning of teliospores. Phytopathology 58:1541-1546.

46. Snow, G. A. 1968. Time required for infection of pine by Cronartium fusiforme and effect of field and laboratory exposure after inoculation. Phytopathology 58:1547-1550.

47. Snow, G. A., Dinus, R. J., and Kais, A. G. 1975. Variation in pathogenicity of diverse sources of Cronartium fusiforme on selected slash pine families. Phytopathology 65:170-175.

48. Snow, G. A., and Kais, A. G. 1970. Pathogenic variability in isolates of Cronartium fusiforme from five southern states. Phytopathology 60:1730-1731.

49. Snow, G. A., Rowan, S. J., Jones, J. P., Kelley, W. D., and Mexal, J. G. 1979. Using Bayleton (triadimefon) to control fusiform rust in pine tree nurseries. U.S. Dep. Agric. For. Serv. South. For. Exp. Stn. Res. Note SO-253.

50. Sohn, S. I., Goddard, R. E., and Schmidt, R. A. 1975. Comparative performances of slash pine for fusiform rust resistance in high rust hazard locations. Pages 204-211 in: Proc. South. For. Tree Improve. Conf., 13th. South. For. Tree Improve. Comm. Pub. No. 35,

51. Squillace, A. E., Dinus, R. J., Hollis, C. A., and Schmidt, R. A. 1978. Relation of oak abundance, seed source, and temperature to geographic patterns of fusiform rust incidence. U.S. Dep. Agric. For. Serv. Southeast. For. Exp. Stn. Res. Pap. SE-186.

52. Starkey, D. A., Anderson, R. L., Young, C. H., Cost, N. D., Vissage, J. S., May, D. M., and Yockey, E. K. 1997. Monitoring incidence of fusiform rust in the South and change over time. U.S. Dep. Agric. For. Serv. South. Reg. For. Health Prot. Rep. R8-PR30.

53. Walkinshaw, C. H., Dell, T. R., and Hubbard, S. D. 1980. Predicting field performance of slash pine families from inoculated greenhouse seedlings. U.S. Dep. Agric. For. Serv. South. For. Exp. Stn. Res. Pap. SO-160.

54. Wilcox, P. L., Amerson, H. V., Kuhlman, E. G., Liu, B. H., O'Malley, D. M., and Sederoff, R. R. 1996. Detection of a major gene for resistance to fusiform rust disease in loblolly pine by genomic mapping. Proc. Natl. Acad. Sci. USA 93:3859-3864. 